\title{
Telaah Kitab Tafsir Firdaus Al-Na'im Karya Thaifur Ali Wafa Al-Maduri
}

\author{
Oleh: Moh. Azwar Hairul
}

Email: azwarhairul616@gmail.com

\section{Fakultas Ushuluddin UIN Syarif Hidayatullah Jakarta}

\begin{abstract}
This article aimed to describe one of the Tafsir which compiled by Ulama Madura named Thaifur Ali Wafa. He is the son of famous Ulama Madura named KH. Ali Wafa. Thaifur's capacity as the Ulama could not be doubted. Inherited the expertise of his father, now he has produced a number of books. One of His magnum opus is Tafsir Firdaus al-Na'im. The Tafsir classified as the unpublished tafsir, so that his Tafsir considerend unnoticed on the studies of The Alquran in Indonesia. Tafsir Firdaus al-Na'im consist complete commentary of Alquran within 30 Chapter and written by Arabic language. It took approximately three year to complete his written. The Methodology of the Tafsir is using the Tahlili method. althought that, the way its explanation not totally as the same Tahlili ways. It viewed with the aspect of interpretation using ijmali analysis with simple explanation, it's feature interpretation could not be affilated to any special pattern. The existance of the Tafsir Firdaus al-Nai'm in the modern era showed the dynamics development of interpretation of the Alquran in Indonesia. at least, this Tafsir could add the treasury of literature interpretation of the Alquran in Nusantara.
\end{abstract}

Keywords: Tafsir Firdaus al-Naim, Tafsir Ulama Madura 


\section{A. Pendahuluan}

Kajian Alquran di Indonesia merupakan kajian yang selalu menarik dan layak mendapat perhatian serius bagi para pengkaji seputar Alquran dan Ilmu Tafsirnya. Hal ini tidak terlepas dari keunikan literatur tafsir nusantara. Disebut unik, sebab, sederet kitab tafsir yang lahir di Indonesia bersentuhan dengan tradisi budaya lokal yang terdapat diberbagai daerah di Indonesia. Hal ini kemudian berpengaruh pada terjadinya vernakularisasi Alquran dengan pembahasaan ke dalam berbagai bahasa lokal Nusantara. Terlebih lagi, pengkajian seputar literatur Tafsir di Indonesia semakin menambah keunikannya dengan karakteristik penulisaan tafsir yang menggunakan huruf aksara lokal. ${ }^{1}$

Kendati demikian, hal itu tidak menafikan tradisi penafsiran Alquran di Indonesia dengan menggunakan Bahasa Arab. Sebab bagaimanapun juga Bahasa Arab merupakan bahasa dari Alquran itu sendiri. Selain itu, beberapa ulama mewajibkan penguasaan Bahasa Arab sebagai salah satu persyaratan untuk menjadi seorang mufasir. ${ }^{2}$ Penggunaan Bahasa Arab dalam tradisi penafsiran Alquran di Indonesia dapat dilihat dengan adanya kitab Tafsir Alquran yang lahir dari goresan tangan ulama Nusantara yaitu kitab Tafsir al-Munir Marah Labid karya Syaikh Nawawi al-Bantani (meskipun tafsir ini tidak ditulis di Indonesia).

Tidak dapat dipungkiri penulisan kitab tafsir di Indonesia sebenarnya telah bergerak sejak lama. Para peneliti sepakat cikal

1 Tafsir Alquran di Indonesia ditulis dengan bahasa dan aksara yang beraneka ragam, dalam hal bahasa, bahasa yang dipakai berasal dari ragam etinis yang ada di Nusantara, seperti bahasa Melayu, Jawa, Sunda, Madura, dan Bugis. Pemakaian bahasa daerah dan aksara dalam penafsiran Alquran di Indonesia mencerminkan tentang keragaman latar belakang tradisi dan budaya serta konteks geografis Indonesia. Dengan penggunaan bahasa dan aksara tersebut menjadi media terbaik untuk menyampaikan nilai-nilai Alquran dalam konteks masyarakat yang lebih luas, meskipun mereka tidak menguasai bahasa Arab dengan baik. Islah Gusmian, Bahasa dan Aksara dalam Penulisan Tafsir Alquran di Indonesia Era Abad 20 M, Jurnal Mutawatir, No. 2 Vol. 2 Juli-Desember 2015, h. 244-255

2 Manna al-Qathan, Mabahits Fi 'Ulum Alquran, Terj. Aunur Rafiq El-Mazni, (Jakarta: Pustaka al-Kautsar, 2006), h. 416 
bakal penafsiran Alquran dimulai pada abad ke-17 ditandai dengan ditemukannya kitab Tarjuman Mustafid karya Abd. Rauf Singkili. Hingga mencapai abad ke-20 literatur Tafsir Alquran dengan semakin berkembang dari segi metode, nuansa dan pendekatan penafsirannya. ${ }^{3}$ Hal ini kemudian menarik berbagai peneliti untuk menghimpun seluruh tafsir Indonesia dengan pemetaan terhadap sejarah penulisan, karakteristik dan pemetaan priode tafsir. ${ }^{4}$

Dari sederet nama tokoh mufasir Indonesia terselip salah satu nama mufasir yang nyaris terlewatkan yaitu KH. Thaifur Ali Wafa dengan kitab Tafsirnya berjudul Firdaus al-Na'im. Dikatakan nyaris terlewatkan, karena memang sosok mufasir dan karya tafsirnya hampir tidak disebutkan oleh beberapa penelitian tentang perkembangan tafsir di Indonesia. Padahal jika dilihat dari masa penulisannya, tafsir tersebut menempati periode abad ke-20 ditinjau dalam pemetaan literatur tafsir Indonesia. Tafsir ini selesai ditulis pada tahun 2013. Agaknya hal ini bisa jadi karena tafsir karangan ulama asal Ambunten Kab. Sumenep Madura ini belum dipublikasikan. Menurut Jajang A. Rohmana, kajian Alquran Indonesia dalam kalangan akademisi lebih banyak terfokus pada kajian Alquran yang muncul dipermukaan dalam jangkauan luas dan tidak melirik tafsir yang dipublikasikan dalam jumlah relatif kecil dan terbatas. ${ }^{5}$

Kajian ini mencoba mengelaborasi "Tafsir Firdaus al-Naim", dengan berpijak pada pertimbangan tafsir tersebut memiliki kekhasan di antaranya: pertama, ditinjau dari aspek latar belakang, tafsir dan

3 Islah Gusmian, Khazanah Tafsir Indonesia: Dari Hermeneutika hingga Ideologi, (Yogyakarta: Lkis, 2013), h. 51

4 Misalnya seperti peneliti Howard Federspiel dalam karyanya Popular Indonesian Literatures on The Quran mencoba menyusun priodesasi penulisat tafsir di Indonesia. Nashruddin Baidan dengan membagi priode tafsir yang ada di Indonesia dalam bukunya yang berjudul Perkembagan Tafsir di Indonesia. Islah Gusmian terbilang cukup komprehensif menghimpun karakteristik perkembangan tafsir nusantara di Indonesia, dalam bukunya Khazanah Tafsir Indonesia Dari Heremenutika hingga Ideologi. Dan masih banyak lagi tulisan akademis baik itu jurnal, skripsi, tesis dan disertasi. Namun hanya saja tidak ada yang menyinggung kitab Tafsir Firdaus al-Na'im karangan Thaifur Ali Wafa.

5 Jajang A. Rohmana, Kajian Alquran di Tatar Sunda: Sebuah Penelusuran Awal, Suhuf, Vol. 6, No. 1, 2013, h. 198. 
penulisnya, tafsir ini lahir di tangan seorang ulama muda asal Madura yang masih hidup. Kedua, kajian tafsir ini ini disampaikan secara khusus pada warga pondok pesantren Al-Saddad Sumenep. Ketiga, penelitian aspek teknis penulisan dan metodologi penafsiran dan lainnya.

\section{B. Biografi Singkat Thaifur Ali Wafa}

Nama lengkapnya adalah Thaifur bin Ali Wafa Muharror alMuduri. Ali Wafa adalah nama dinisbahkan kepada nama ayahnya, seorang ulama tersohor paling berpengaruh di Madura. Menurut Martin Van Bruinessen, KH. Ali Wafa memiliki reputasi yang sangat gemilang baik dilihat secara pribadinya sebagai seorang ulama maupun bagi Tarekat Naqsyabandiyah. Bahkan, jika tidak berlebihan, tidak ada pengganti (khalifah) yang menyamai reputasi KH. Ali Wafa. ${ }^{6}$ Oleh karena itu, tidak mengherankan jika Thaifur memiliki keilmuan agama yang luas. Thaifur mewarisi intelektualitas ayahnya. Dalam pengakuannya menyebut sosok ayah hanyalah memiliki andil besar dalam membentuk pemikirannya. ${ }^{7}$

Selain iu, Thaifur pernah menempuh pendidikan di Mekkah selama 7 Tahun. Selama di Mekkah Thaifur berguru kepada seorang ulama asal Yaman yang bernama Syaikh Ismail. Bagi Thaifur, selain Ayah, Syaikh Ismail ini pula yang turut banyak mewariskan ilmu kepadanya. ${ }^{8}$

Kini Thaifur memangku jabatan sebagai salah satu guru Tarekat Naqshabandiyah Mudzahriyah. ${ }^{9}$ Dia menerima ijazah dari seorang ulama berasal dari Malang bernama KH. Lathifi Baidowi, yang juga

6 Martin Van Bruinessen, Kitab Kuning, Pesantren dan Tarekat: Tradisi Islam di Indonesia, (Bandng: Mizan, 1995), h. 120.

7 Wawancara dengan Thaifur, Tanggal 2 November 2016

8 Wawancara dengan Thaifur, Tanggal 2 November 2016

9 Tarekat Naqsyabandiyah Muzhariyah merupakan salah satu cabang tarekat Naqsyabandiyah yang berkembang di Indonesia. Tarekat Naqsyabandiyah sendiri didirikan oleh Muhammad Baha al-Din al-Uwaisi al-Naqsyabandy (w. 1399 M.). Risan Rusli, Tasawuf dan Tarekat: Studi Pemikiran dan Pengalaman Sufi, (Jakarta: RajaGrafindo, 2013), h. 212 
merupakan murid yang menerima ijazah dari ayahnya. ${ }^{10}$ Thaifur mengaku menerima ijazah dari KH. Lathifi saat beliau berusia 33 Tahun.

Di bawah kepemimpinan Thaifur, secara keseluruhan Tarekat Naqsabandiyah Mudzhariyah memiliki ribuan jama’ah menyebar di beberapa kecamatan di Kabupaten Sumenep, sepeti: Kec. Ambunten, Kec. Gapura, Kec. Batang-Batang, dll. Tidak hanya di daerah daratan, melainkan juga di kepulauan, seperti di kepulauan Sepudi. Bahkan, konon ada juga seperti Kalimantan.

Namun untuk saat ini, Thaifur Ali Wafa sedang tawakuf (baca: istirahat) dari kegiatan tarekat. Sewaktu aktif, kegiatan tarekat ini biasa diselenggarakan setiap Jum'at pagi. Kegiatan tersebut diberi nama "Khatmil Khawajakan" Oleh orang Madura disebut "hojhegen". Aktifitas Thaifur kini sebagai pemimpin Pondok Pesantren al-Saddad Ambunten, Sumenep dan banyak mengabdikan diri di masyarakat dengan mengisi ceramah di berbagai daerah di Madura. ${ }^{11}$

Thaifur Ali Wafa al-Muduri dapat dikatakan adalah ulama yang produktif. Thaifur mempunyai banyak karya yang terdiri dari kitab-kitab berbahasa Arab dan Indonesia. Adapun karya terbesar beliau adalah kitab Tafsir Firdaus al-Naim yang terdiri dari 6 Jilid, sedangkan karya-karya lainnya adalah :Bulghattullab, Tanwirul Baso'ir, Alfarqudurrofi', Haba'ilu al Syawarid, Misykatul Anwar, Al Roaudun Nazhir, Kuthufud Daniyah, Sullamul Qashidin, Miftahul Ghawamid. Buku berbahasa Indonesia: Menyikap Tirai Kehidupan Nabi dan Tetestetes Darah Perempuan.

\section{Profil dan Karakteristik Kitab Tafsir Firdaus al-Naim}

\section{Ciri-Ciri Umum}

Nama kitab tafsir ini dapat dilihat pada sampul depan yang berwarna hijau. Pada bagian atas tertulis "Firdaus al-Na'im bi Taudih

10 Martin Van Bruinessen, Kitab Kuning, Pesantren dan Tarekat,.... h. 120

11 Wawancara dengan Thaifur Ali Wafa, Tanggal 2 November 2016 
Ma'ani 'ayat Alquran al-Karim". ${ }^{12}$ Berdasarkan pengakuan Thaifur, dinamakan "Firdaus al-Naim" merujuk dari salah satu nama surga yaitu "Jannah al-Firdaus". ${ }^{13}$ Hal ini menurutnya sebagai wujud aktualisasi atau dalam istilah Bahasa Arab disebut sebagai Tafa'ul yakni; sebuah upaya disertai dengan harapan melalui tafsir ini dapat mengantarkan mufasir dan begitu juga para pencinta Alquran yang senantiasa mengkajinya untuk menggapai kenikmatan surga kelak. ${ }^{14}$

Tafsir ini ditulis dengan Bahasa Arab. Penulis tafsir cenderung memilih Bahasa Arab dibanding Bahasa Madura sebab sasaran utama dari tafsir ini tidak hanya khusus masyarakat Madura saja. Menurutnya, Bahasa Arab merupakan bahasa yang lebih utama di samping sebagai Bahasa Alquran sendiri, Bahasa Arab pula menurutnya bahasa yang mudah dipelajari. Dengan begitu, tafsir ini dapat dikaji dan dibaca lebih dalam lingkup yang lebih luas dan khususnya juga di Pondok Pesantren dan berbagai kalangan lainnya yakni para pengkaji studi Islam. ${ }^{15}$

Tafsir ini belum diterbitkan oleh penerbit resmi. Thaifur pernah mencoba mengajukan pada beberapa penerbit, namun hanya saja terkendala pada persoalan finansial. Untuk menerbitkan karya yang terdiri dari 6 jilid ini menurutnya memerlukan dana yang besar. Oleh karena itu, penulis tafsir berinisiatif untuk memperbanyak karangannya ini secara mandiri. Tafsir ini ditulis dalam kurun waktu 3 Tahun dan selesai ditulis pagi hari tepat pada tanggal 21 Rabi'ul Awwal $1434 \mathrm{H}$ yang bertepatan dengan tanggal 12 Februari 2013. ${ }^{16}$

Penulisan tafsir ini diketik menggunakan font "Traditional Arabic" dalam bentuk huruf tebal (bold), kemudian di-print out menggunakan kertas HVS berukuran 16.5 X $22 \mathrm{~cm}$. Tafsir ini terdiri dari 6 jilid yang menghimpun seluruh penafsiran 114 Surah Alquran. Rata-rata

12 Abu Muhammad Thaifur Ali Wafa, Firdaus al-Naim Bi Tudih Mána Ayat al-Quran alKarim, (tth), Jilid I, h. 2

13 Dalam Alquran surga Firdaus disebutkan dua kali pada QS. al-Kahfi [18]: 107 dan QS. al-Mu'minun [23] : 11

14 Wawancara dengan Thaifur Ali Wafa, tanggal 3 November 2016

15 Wawancara dengan Thaifur Ali Wafa, tanggal 3 November 2016

16 Abu Muhammad Thaifur Ali Wafa, Firdaus al-Naim bi Taudih Ma'na Ayat al-Quran alKarim, (tth), Jilid I, h. 455 
setiap jilid terdiri \pm 400 lebih halaman. Dalam spesifikasinya, penulis tafsir membagi setiap jilid ke dalam beberapa kelompok juz. Berikut rinciannya :

\begin{tabular}{|c|l|l|c|}
\hline No. & Jilid & \multicolumn{1}{|c|}{ Konten } & $\begin{array}{c}\text { Jumlah } \\
\text { halaman }\end{array}$ \\
\hline 1 & Jilid I & $\begin{array}{l}\text { Pendahuluan, Surah al-Fatihah s/d Surah } \\
\text { al-Nisa (permulaan Juz 6 La Yuhibbullah } \\
\text { Jahra bil su') }\end{array}$ & 527 \\
\hline 2 & Jilid II & $\begin{array}{l}\text { Surah al-Maidah s/d Surah al-Taubah } \\
\text { (Permulaan Juz 11 ya'taziruna ilaikum) }\end{array}$ & 600 \\
\hline 3 & Jilid III & $\begin{array}{l}\text { Surah Yunus s/d Surah Isra } \\
\text { (Permulaan Juz 15 "Subhana allazi Asra) }\end{array}$ & 520 \\
\hline 4 & Jilid IV & $\begin{array}{l}\text { Surah al-Naml s/d Surah al-Ankabut } \\
\text { (Permulaan Juz 21 “Wa la tujadilu ahla al- } \\
\text { Kitab) }\end{array}$ & 562 \\
\hline 5 & Jilid V & Surah al-Rum s/d Shaffat (Juz 13) & 450 \\
\hline 6 & Jilid VI & Surah al-Ahqaf s/d al-Nas & 463 \\
\hline
\end{tabular}

Tabel I : Rincian Konten Tafsir Firdaus Al-Na’im

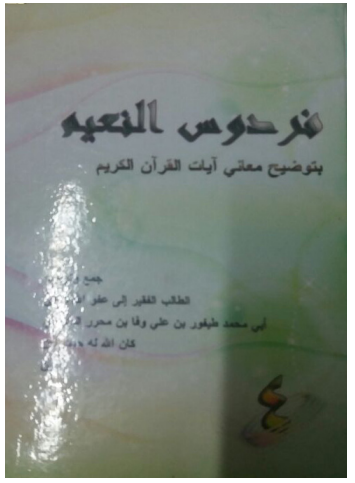

Gambar I : Sampul Depan

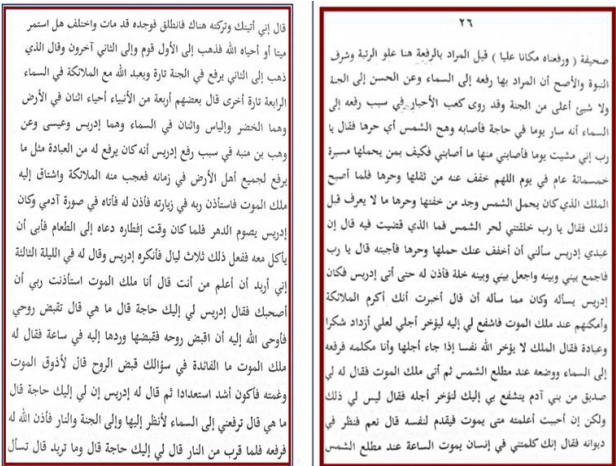

Gambar II : Mushaf Tafsir Firdaus alNai'im

\section{Latar Belakang dan Tujuan Penulisan Tafsir}

Pada bagian pendahuluan, Thaifur menyebutkan bahwa keagungan Alquran sebagai mukjizat kekal yang memuat hamparan 
ayat Alquran yang mempesona. Mengutip QS. al-Hashr [59]: 21 Thaifur menyatakan ayat ini menggambarkan kerugian bagi orang-orang kafir yang mengingkari keagungannya, sementara keberadaan Alquran di sisi seorang mukmin merupakan suatu keberuntungan dan kemuliaan bagi mereka. Dari sini Thaifur hendak mengingatkan sisi kemukjizatan Alquran bagi para pembacanya. Kemudian Thaifur mendorong para kaum mukmin untuk senantiasa "bersibuk ria" membaca Alquran. Sembari memotivasi para pembaca Alquran, Thaifur mengutip sebuah hadis yang diriwayatkan Hakim, bahwa para "Keluarga Allah adalah mereka para ahli Quran yaitu orang-orang menjaga dan menghafalkannya”. Namun hanya saja untuk memperoleh derajat ini menurutnya harus disertai upaya mendekatkan diri kepada Allah disertai harapan untuk memperoleh kecintaan dari-Nya. ${ }^{17}$

Tidak hanya itu, dari tafsir ini, Thaifur juga hendak memahamkan kepada pembaca bahwa Alquran tidak hanya memuat arti harfiahnya saja akan tetapi juga terdapat makna batin yang khusus dipahami bagi mereka yang khusyuk dan senantiasa tunduk pada sang pencipta. Mereka inilah orang-orang beruntung. Namun kesemuanya itu tidak akan tercapai kecuali dengan mengetahui makna tersuratnya terlebih dahulu. ${ }^{18}$ Gagasan yang dikemukakan oleh Thaifur ini identik dengan cara pandang para sufi dalam memandang Alquran tidak hanya pada kandungan tekstualnya saja tetapi ada makna yang lebih dalam lagi yang lebih utama, dan manusia mempunyai kemampuan untuk memahami itu. ${ }^{19}$ Agaknya dari ungkapan itu, Thaifur tidak bisa lepas dari pribadinya yang juga mendalami ilmu tasawuf dan sekaligus pelaku tasawuf amali dalam aktifitas tarekat.

Memang dalam tradisi tafsir yang cenderung mengusung spirit makna batin Alquran sebagaimana identik dalam kalangan para sufi,

17 Abu Muhammad Thaifur Ali Wafa, Firdaus al-Naim Bi Tudih Ma'na Ayat Alquran alKarim, (tth), Jilid I, h. 2

18 Abu Muhammad Thaifur Ali Wafa, Firdaus al-Naim Bi Tudih Ma'na Ayat Alquran alKarim, Jilid I, h. 3

19 Kristin Zahra Sands, Sufi Commentaries on The Quran in Classical Islam, (London \& New York, (London \& New York: Routledge, 2006), h. 7 
keniscayaan memahami makna zahir terlebih dahulu adalah suatu keharusan sebelum mengekstrak makna batinnya. Keharusan itu pernah diungkapkan oleh Imam Ghazali dalam sebuah bentuk analogi yang menyatakan bahwa perumpamaan orang-orang yang mengklaim telah memahami rahasia-rahasia Alquran (asrar quran) tanpa pernah menguasai tafsir zahirnya, adalah seperti orang yang mengklaim telah mencapai ruang inti rumah (sadr al-Bait) tanpa pernah melewati pintunya atau seperti yang mengklaim telah memahami maksud orang-orang Turki dari perkataan mereka tanpa memahami Bahasa Turki. Tafsir lahiriah seperti belajar bahasa sangat dibutuhkan untuk memahami Alquran. ${ }^{20}$ Kendati demikian, dalam tafsir karya Thaifur Ali Wafa ini dapat dikatakan tidak memuat dimensi sufistik yang begitu kental. Hal ini agaknya tidak terlepas dari motivasi utama yang dikemukakannya tadi. Bahwa pemahaman makna zahir adalah utama sebelum menangkap rahasia kandungan makna Alquran.

Lepas dari hal tersebut, satu hal yang menarik dari pengakuan Thaifur dalam pendahuluannya, bahwa karya Tafsir ini hanya berupa nukilan dari ungkapan para mufasir yang dituangkan dalam karya tulis yang diibaratkannya hanya sebagai Perjalanan Singkat "al-Safr al-Shagir". Oleh karena itu, boleh jadi kita dapat meragukan orisinalitas tafsir ini. Namun yang patut diakui, dengan pemahaman Bahasa Arab yang baik, Thaifur sangat lihai menguraikan penafsirannya dengan bahasa yang disusunnya sendiri.

Sebagai seorang tokoh dan panutan masyarakat Sumenep dalam bidang keagamaan. Berbekal kemampuan Bahasa Arab yang ditekuninya semenjak menuntut ilmu di pondok pesantren, ditambah lagi selama 7 Tahun di Mekkah, ia merasa terpanggil untuk memberikan kontribusi keilmuan dalam bidang tafsir Alquran dengan menyajikan metode penulisan yang sistematis, dan bahasa yang sederhana dan efektif untuk dibaca dan dipahami.

20 Nicholas Heer, Tafsir Esoteris Alquran Abu Hamid al-Ghazali dalam Leonard Lewishon dkk, Warisan Sufi: Sufisme Persia Klasik hingga Rumi (700-1300), Terj. Gafna Raizha Wahyudi, (Yogyakarta:Pustaka Sufi, 2002), h. 301-302 


\section{Sistematika Penyajian Tafsir}

Sebagaimana yang telah dikemukakan sebelumnya, tafsir ini disajikan dalam penjelasan yang sederhana. Maka jika diperhatikan secara sistematis penyajian tafsir ini dilakukan dalam beberapa langkah yaitu :

1) Mengawali penafsirannya, Tafsir Firdaus al-Naim menjelaskan nama surah berserta jumlah ayat, kalimat dan bahkan juga jumlah hurufnya. Misalnya, Surah al-Baqarah yang disebutkannya terdiri dari 287 ayat, 3100 kalimat, 52.000 huruf, dalam penjelasannya juga tidak lupa menyertakan kategorisasi posisi turunnya ayat, apakah Makkiyah atau Madaniyah. Terkadang juga menyebutkan nama-nama lain dari sebuah surah beserta hikmahnya. Misalnya Surah al-Fatihah, penamaan surah ini tidak lain karena surah ini sebagai pembuka dalam Alquran dan juga di setiap awal salat ditandai dengan membaca surah ini. Disebut juga "Umm al-Kitab", "Umm Alquran”. dan "Sab'ah al-Matshani" sebab salah satu kandungan surah ini memuat pujian kepada Allah yang dibaca berulang-ulang setiap rakaat salat.

2) Menyusun kategorisasi ayat untuk dijelaskan yang ditulis dalam tanda kurung ( ) yang kemudian dijelaskan dengan penjelasan rinci seraya menjelaskan maksud mendasar dari ayat. Akan tetapi dalam penafsirannya Thaifur tidak menyebutkan nomor ayatnya. Karena itu, pembaca menemui kesulitan untuk mencari penjelasan dari ayat tertentu. Jika dilihat cara penyajian Thaifur mirip dengan cara kerja Ali Shabuni dalam karangan tafsirnya Shafwatu al-Tafasir ${ }^{21}$ atau Tafsir al-Munir (Marah Labid) karya ulama Nusantara Syaikh Nawawi al-Bantani.

21 Ali al-Shabuni merupakan salah satu ulama yang terkenal dengan kedalaman ilmunya. Hal itu terlihat begitu produktifnya ulama kelahiran Syiria ini. Salah satu karya terbesarnya yaitu sebuah Tafsir yang diberi nama Shafwa al-Tafasir yang ditulis kurang lebih lima tahun, selesai tepat pada tahun 1930. Tafsir ini terdiri dari 3 Jilid. Dengan menggunakan metode sederhana sehingga tafsir ini mudah dipahami dan tidak mempersulit para pembaca. Ali al-Shabuni, Shafwa al-Tafasir, (Beriut: Darul al-Fikr, 1987), h. 20 
3) Terkadang juga menjelaskan aspek bahasa tertentu jika ada kalimat yang menurutnya perlu dijelaskan secara gramatikal. Misalnya pada QS. Tahrim (66): 8 "asa rabbukum an yukaffira ankum sayyiatikum wayudkhilakum jannatin tajrim min tahtihal anhar yauma la yukhzi allahu nabiya wallazina ma'ahu." Menurutnya kalimat "al-Nabiya" mengikuti bentuk manshub dari kata yudkhilakum. Adapun pemberhentian pada kalimat "wa allazina ma'ahu" merupakan sebagai bentuk waw istinaf sehingga dapat dikatakan sebagai mubtada' dan khabarnya adalah kalimat selanjutnya "nuruhum yas'a". ${ }^{22}$

4) Menyebutkan jenis Qiraat sebelum menjelaskan maksud dari suatu ayat. misalnya pada QS. al-Fathir (35) : 9 "Ila Baladin Mayyitin". Dalam bacaan Nafi', Hafas, Hamzah dan Kisa'i membaca dengan tasydid (mayyitin). Sementara para Qari' lainnya membaca dengan sukun (maitin). Adapun maksud dari kalimat "Baladin Mayyitin" pada ayat ini adalah sebuah negeri yang gersang, tidak ada tumbuhan dan tidak ada hewan ternak. $^{23}$

5) Menyebutkan sebab turunnya ayat (asbab al-Nuzul) bilamana suatu ayat yang kiranya perlu disebutkan sebab turunnya. Dalam menyebut sebab turunnya ayat, Thaifur membuang perawinya dan tidak menyebutkan sumber asli dari mana riwayat tersebut. Misalnya ketika menjelaskan QS. alTaghabun (64): 14 yang meriwayatkan kisah seorang lelaki yang hendak berhijrah bersama nabi. Akan tetapi istri dan anak mereka enggan berhijrah. Dalam riwayat lain disebutkan ayat ini secara khusus kepada Auf bin Mali al-Syaja'i yang mempunyai anak dan seorang anak. Ketika Auf hendak berhijrah istri dan anaknya menangis dan menahannya agar tidak berangkat berhijrah dan berkata kepada siapa kami

22 Abu Muhammad Thaifur Ali Wafa, Firdaus al-Naim Bi Tudid Ma'na Ayat Alquran alKarim, Jilid VI, h. 260

23 Abu Muhammad Thaifur Ali Wafa, Firdaus al-Naim Bi Tudid Ma'na Ayat Alquran alKarim, Jilid V, h. 177 
ditinggalkan? Dengan begitu, Thaifur tidak melupakan bahwa pemahaman asbab nuzul merupakan aspek yang penting dalam penafsiran Alquran. ${ }^{24}$

\section{Metode dan sumber Tafsir Firdaus al-Naim}

Sebagaimana lazimnya suatu kitab tafsir memiliki sebuah metode sebagai acuan untuk memaparkan penjelasan ayat Alquran. Setiap mufasir memiliki metode dan kecenderungan yang berbeda-beda dalam menafsirkan. Para ahli terdahulu telah sepakat merumuskan beberapa metode tafsir dalam 4 cara yakni; (1) ijmali (penjelesan makna global), tahlili (analisis), muqaran (komparasi) dan maudhu'i (tematik). ${ }^{25}$

Jika diperhatikan, maka metode penafsiran Thaifur Ali Wafa ditempuh dengan cara tahlili. Metode tahlili adalah suatu metode tafsir yang mufasirnya berusaha menjelaskan kandungan ayat-ayat Alquran dari berbagai segi dengan memperhatikan urutan ayat Alquran sesuai dengan yang tercantum dalam Mushaf Usmani. ${ }^{26}$

Meskipun dikategorikan sebagai tafsir yang menggunakan metode tahlili, tetapi dalam penjelasannya Thaifur tidak terlihat menggunakan cara kerja seperti dengan tafsir-tafsir yang menggunakan metode ini, dengan menganalisis berbagai aspeknya secara mendetail dan menjelaskan secara panjang lebar. Agaknya, ini tidak lain bertujuan untuk memudahkan para pembaca tafsirnya unuk tidak disibukkan

24 Abu Muhammad Thaifur Ali Wafa, Firdaus al-Naim Bi Tudid Ma'na Ayat al-Quran alKarim, Jilid VI, 244

25 Qurasih Shihab, Membumikan Alquran: Fungsi dan Peran Wahyu dalam Kehidupan Masyarakat (Bandung:Pustaka Mizan, 2009), h.129

26 Dibandingkan dengan metode tafsir lainnya, metode tahlili atau yang oleh Baqir al-Shadr disebut dengan istilah lain dengan tafsir tajzi'i merupakan metode yang paling tua. Tafsir ini bermula sejak masa para sahabat nabi saw. pada mulanya terdiri dari tafsiran atas beberapa ayat saja, yang kadang-kadang mencakup mengenaik kosa katanya. Seiring dengan perjalan waktu para ulama tafsir merasakan kebutuhan adanya tafsir yang mencakup seluruh isi Alquran. karenanya pada akhir abad ke-4 Hijriah Ahli-hali Tafsir seperti Ibn Majah, al-Thabari dan lain-lain lalu mengkaji keseluruhan isi Alquran dan membuat model-model paling maju dari tafsir tahlili ini. Quraish Shihab dkk, Sejarah dan Ulum Alquran, (Jakarta: Pustaka Firdaus, 2008), h. 177 Lihat juga Qurasih Shihab, Membumikan Alquran: Fungsi dan Peran Wahyu dalam Kehidupan Masyarakat ,h.130 
dengan berbagai analisisnya, sehingga mereka dapat lebih cepat memahami kandungan ayat-ayatnya. Maka dari itu, dari segi uraiannya yang ditampilkan, cara kerja Thaifur lebih cocok disebut dengan menggunakan analisis ijmali, meskipun dari segi penyajian runtutan pembahasan tafsir mengikuti tertib ayat Mushaf Usmani. Dalam hal ini, mufasir ketika menafsirkan ayat Alquran menggunakan uraian yang ringkas, tidak berbelit-belit namun mencakup maksud ayat Alquran dengan menggunakan gaya bahasa populer ${ }^{27}$, mudah dimengerti dan enak dibaca. Hal ini merupakan salah satu keunggulan metode ijmali. ${ }^{28}$

Dari segi sumber yang digunakan, selain menggunakan ayat Alquran dan hadis yang identik dengan bentuk tafsir bi al-Mastur, Tafsir Firdaus al-Na'im juga menggunakan pendekatan nalar (ra'yi) sebagai sumber dalam menafsirkan ayat-ayat Alquran. Hal ini terlihat ketika mufasir turut menjelaskan kandungan makna suatu ayat dengan menganalisis aspek kebahasaannya disertasi argumen dari mufasir. ${ }^{29}$ Kendati demikian, tafsir ini juga tidak terbebas dari riwayat-riwayat

27 Islah Gusmian menyebutkan gaya penulisan tafsir memiliki empat bentuk: pertama, gaya penulisan kolom yaitu gaya penulisan tafsir dengan memakai kalimat yang pendek, lugas, dan tegas. Dalam aplikasinya biasanya menggunakan diksi yang dipilih melalui proses selesksi yang serius dan akurat. Kedua, gaya bahasa penulisan reportase yaitu dengan menggunakan kalimat yang sederhana, elegan, komunikatif, dan lebih menekankan pada hal yang bersifat pelaporan, dan bersifat human interest. Gaya bahasa semacam ini biasanya seperti dalam bentuk reportase yang sering digunakan dalam majalah koran yang menyajikan laporan dari berbagai peristiwa penting. Ketiga, gaya penulisan ilmiah yaitu suatu gaya bahasa penulisan yang dalam proses komunikasinya terasa formal dan kering. Gaya bahasa ini cenderung digunakan oleh buku-buku yang ditulis dari tugastugas akademik. Keempat, gaya penulisan populer yang sasaran utamanya menempatkan bahasa sebagai medium komunikasi dengan karakater kebersahajaan. Kata dan kalimat yang digunakan, dipilih yang sederhana dan mudah sehinggah memudahkan pembaca dalam menanggkap, memahami makna yang terkandung dalam Alquran. Lihat, Islah Gusmian, Khazanah Tafsir Indonesia: dari Hermeneutika hingga Ideologi, h. 174-180

28 Nasruddin Baidan, Metodologi Penafsiran Alquran, (Yogyakarta: Pustaka Pelajar, 2002), h. 13

29 Secara bahasa 'ra'yi' berarti keyakinan (i'tiqad), analogi (qiyas), dan ijtihad. Dalam terminologi ilmu Tafsir adalah ijtihad. sehingga tafsir bi al-ra'yi juga biasa disebut sebagai tafsir bi al-dirayah. Dalam definisi Husein al-Zahabi, tafsir bi al-ra'yi adalah tafsir yang menjelaskan berdasarkan ijtihad seorang mufasir setelah mengetahui bahasa arab dan metodenya, dan pemahaman terhadap aspek ilmu Alquran lainnya, seperti asbab nuzul, nasikh dan mansukh dan sebagainya. Lihat Rosihan Anwar, Pengantar Ulumul Quran, (Bandung: Pusataka Setia, 2009), h. 188 
israiliyat. Dalam penafsirannya, Thaifur juga mengutip riwayat-riwayat ganjil. Misalnya ketika menjelaskan ayat kisah Nabi Daud, seperti yang termuat dalam QS. Maryam (19): 57 "wa rafa'nahu makanan 'aliyan”. ${ }^{30}$

Tidak dapat dipungkiri, Tafsir Firdaus al-Na'im sangat dipengaruhi oleh beberapa karya tafsir sebelumnya, terutama dalam kitab tafsir Hasyiyah Ash-Shawi karya Syaikh Ahmad bin Muhammad AshShawi Al-Mishri Al-Maliki Al-Khalwati (w. 1241 H) dan Kitab Tafsir Lubaab al-Ta'wil fi ma'aani al-Tanzil atau lebih dikenal dengan Tafsir al-Khazin merujuk pada nama pengarangnya Ala' al-Din Abu Hasan Ali Abu Muhammad ibn Ibrahim ibn Umar ibn Khalil al- al-Baghdadi al-Syafi'I al-Khazin (w.741 H).

Sumber rujukan selain kedua kitab tafsir di atas, yang juga dikutip oleh Thaifur dalam tafsirnya adalah kitab Tafsir al-Jami li Ahkam Alquran karangan Abu Abdulullah al-Qurthubi (w. 671 H), Tafsir Mafatih al-Ghaib (Tafsir al-Kabir) karya Imam Fakhr Ruddin al-Razi (w.610 H). Selain itu, terdapat beberapa kitab tafsir yang bernuansa sufistik yang dikutip antara lain seperti kitab Tafsir al-Jilani karya Shaikh Abd. Qadir al-Jilani. (w. $561 \mathrm{H}$ ). Kitab Tafsir al-Quran al-Karim sebuah kitab tafsir yang dinisbahkan kepada Ibnu 'Arabi (w.1240 H.) dan Tafsir Ruh al-Màni karya Shihabuddin al-Alusi (w. 1270 H.) dan tidak lupa Thaifur mengutip Tafsir karya ulama Nusantara Nawawi al-Bantani (w. 1314 H.) dengan buah tangannya Tafsir al-Munir li Ma'alim al-Tanzil (Tafsir Marah Labid). ${ }^{31}$

\section{Corak Tafsir}

Kajian Alquran mengalami perkembangan pesat seiring dengan dinamika kondisi sosial-budaya dan peradaban manusia. Hal ini dibuktikan dengan lahirnya berbagai macam karya tafsir dengan berbagai corak, metode, dan pendekatan yang digunakan. ${ }^{32}$

Seiring dengan berkembangnya pengetahuan masyarakat maka

30 Abu Muhammad Thaifur Ali Wafa, Firdaus al-Naim Bi Tudid Ma'na Ayat Alquran alKarim, Jilid IV, h. 26-28

31 Wawancara dengan Thaifur Ali Wafa, tanggal 3 November 2016

32 Abdul Mustaqim, Epistemologi Tafsir Kontemporer, (Yogyakarta : LKiS, 2010) h. 1 
munculah berbagai kitab atau penafsiran Alquran yang beraneka ragam coraknya. Hal ini dimaknai sebagai konsekuensi logis dari perkembangan zaman dan pengetahuan, karena Alquran sendiri memberikan kemungkinan-kemungkinan arti yang tidak terbatas. ${ }^{33}$ Adanya corak-corak penafsiran yang beragam adalah bukti akan adanya kebebasan dalam menafsirkan Alquran. Corak-corak tafsir yang ada atau dikenal selama ini yaitu: corak bahasa $(a d a b i)^{34}$, corak filsafat dan teologi (falsafi) ${ }^{35}$, corak penafsiran ilmiah ('Ilmi $)^{36}$, corak fikih $(f i q h i)^{37}$, corak sastra-budaya, corak tasawuf $(\text { sufi })^{38}$, dan yang terakhir kemasyarakatan (adab al-ijtima'i) ${ }^{39}$

Corak penafsiran adalah kecenderungan pemikiran atau ide yang mendominasi dalam sebuah penafsiran. Dalam menentukan sebuah corak dalam penafsiran dapat dilacak pada dominan atau tidaknya sebuah pemikiran atau ide dalam sebuah penafsiran. Menurut

33 Quraish Shihab, Membumikan Alquran:Fungsi dan Peran Wahyu Dalam Kehidupan Masyarakat, h.72

34 Corak ini muncul akibat pengaruh banyaknya orang non-Arab yang memeluk agama Islam, serta akibat kelemahan orang Arab sendiri dalam memahami sastra, sehingga mereka merasa membutuhkan untuk menjelaskan keistimewaan gaya bahasa Alquran dan kedalaman kandungan maknanya.

35 Adapun corak falsafi atau teologi sangat akibat penerjemahan kitab-kitab filsafat yang mempengaruhi beberapa mufasir. Selain itu, masuknya penganut agama-agama lain ke dalam Islam yang masih dipengaruhi oleh kepercayaan lama mereka.

36 Corak ini muncul akibat kemajuan ilmu pengetahuan dan usaha penafsiran untuk memahami ayat-ayat Alquran yang sejalan dengan perkembangan sains, bagi mereka, ulama yang mendukung tafsir ilmi, meyakin bahwa Alquran mendorong umat Islam untuk memerdekakan akal dan melepaskan belenggu berpikir, dan mendorong untuk mengamati fenomena alam. Lihat Rosihan Anwar, Ilmu Tafsir, (Bandung: Pustaka Setia, 2000), h. 170

37 Akibat berkembangnya ilmu fiqhi, dan banyaknya mazhab-mazhab fiqhi, yang setiap golongan berusaha membuktikan kebenaran pendapatnya berdasarkan penafsiranpenafsiran mereka terhadap ayat-ayat hukum.

38 Adapun penafsrian sufi tidak terlepas dari timbulnya gerakan-gerakan sufi sebagai respon terhadap kehidupan manusia yang sangat materialistis yang mengakibatkan manusia kehilangan spiritualitasnya. Munculnya tafsir sufi seiring dengan era penerjemahan karyakarya filsafat Neo-Platonisme di dunia Islam, seperti al-Futuhat al-Makiah dan Fususush al-Hikam karya Muhyiddin Ibn A'rabi, Haqaiq al-Tafsir karya Abu Ubayd Abdurrahman al-Sulami. Lihat M. Jamil, Pergeseran Epistemologi Dalam Tradisi Penafsiran Al-Quran, Jurnal Ilmiah Abdi Ilmu Vol. 4 No. 1 Juni 2011, h. 475.

39 Corak penafsiran ini berusaha menjelaskan petunjuk-petunjuk al-Quran yang berkaitan langsung dengan dinamika kehidupan masyarakat. corak ini diduga muncul pertama kali pada zaman Syaikh Muhammad Abduh. 
Nashruddin Baidan, tipologi corak penafsiran Alquran dapat terbagi menjadi tiga: 1) Corak umum yaitu kecenderungan pemikiran seorang mufasir yang tidak mengkhususkan satu corak dalam penafsirannya, atau dapat dikatakan dalam tafsirannya minimal teradapat tiga corak sekaligus dan ketiganya tidak ada yang dominan karena setiap corak mempunyai porsi yang sama. 2) Corak khusus merupakan corak lebih dominan dalam suatu penafsiran. 3) Corak kombinasi yaitu corak yang menggabungkan dua kecenderungan pemikiran sekaligus. Keduanya mendapat porsi yang sama tanpa mengistimewakan salah satunya. ${ }^{40}$

Dalam konteks Tafsir Firdaus al-Naim dapat dikatakan tidak didominasi satu corak yang menonjol dalam penafsirannya. Melihat latar belakang dia yang seorang pegiat ilmu tasawuf yang berhaluan Tarekat Naqshabandiyah, namun hal itu tidak menjadikan tafsir ini didominasi oleh kecenderungan sufistik. Menurut Thaifur sebagaimana yang telah dikemukakan di pendahuluannya bahwa tafsir ini hanya berupa pengantar kepada para pemula yang hendak mempelajari Alquran dan tidak lain hanya berupa nukilan-nukilan dari para mufasir yang dikutipnya. Sehingga tafsir ini dapat dikatakan bercorak umum tanpa mengkhususkan satu corak dalam penafsirannya.

Namun bukan berarti pemikiran sufistik sama sekali tidak tertuang dalam penafsirannya. Ketika mendapati ayat-ayat Alquran yang identik dalam kredo para mufasir sufi, Thaifur turut menguraikan penafsirannya dengan merujuk pada pendapat para sufi. Sehingga, penafsirannya hanya diuraikan dalam penjelasan yang sederhana. Misalnya ketika menerangkan makna dari QS. al-Nur [24]: 35, dalam istilah para sufi biasanya ayat ini disebut "Ayat Cahaya". ${ }^{41}$ Penafsiran Thaifur terkait ayat ini dapat dilihat sebagai berikut:

40 Nashruddin Baidan, Wawasan Baru ilmu Tafsir, (Pustaka Pelajar: Yogyakarta, 2005), h. 388. 41 Ayat Cahaya adalah Surat Nur ayat 35. Surat ini merupakan salah satu ayat yang banyak menginpirasi para sufi. Tak heran jika ayat ini menjadi salah satu tema sentral dalam beberapa karya sufi. Salah satunya dalam karya momental al-Ghazali yaitu Misykat alAnwar. Dalam karya ini al-Ghazali mencoba memfokuskan pembahasan metafisika Cahaya merujuk pada kata "Nur" dengan pendekatan esoterik dan juga filosofis dan cenderung berbeda jauh dengan penafsiran ulama sebelumnya. Lihat Salahuddin, Tafsir Ayat Cahaya Dalam Misykat Al-Anwar dan Orientas Pendidkan Potensi Diri, Jurnal Lentera Pendidikan, Vol. 12, No. 1 Juni 2009, h. 9 
Ketika menjelaskan kalimat "lillahi nur samawati wa al-ardh" Thaifur mengungkapkan bahwa maksud atau makna hakiki dari kata "Nur" (Cahaya) pada ayat ini bukanlah seperti yang dipahami para mufasir yang cenderung melihat makna zahirnya saja dan terkadang mencoba mentakwilkan ayat ini secara berlebihan yakni; memaknai Allah memberikan cahaya pada langit dengan matahari langit, bulan, bintang, dan Arsy dan para malaikat dan memberikan cahaya pada bumi dengan cahaya pelita, atau lilin melalui para nabi, ulama, dan orang-orang saleh. Akan tetapi makna dari "Nur" di sini adalah Allah sebagai pemberi petunjuk kepada siapa yang dikehendakinya.

Kemudian, Ayat "matsaluhu nurihi" adalah cahaya yang memiliki sifat yang unik, bukan sembarang cahaya. Sifatnya begitu mengesankan. Sembari mengutip pendapat Ibnu Abbas, Thaifur menyatakan bahwa cahaya itulah yang diberikan kepada orang mukmin ke dalam hatinya. Kemudian Thaifur menarik makna-makna dari potongan kalimat (alMisbahu fihi zujajah) dengan pemaknaan yang alegoris, bahwa ayat ini menunjukkan ibarat sebuah badan manusia yang di dalamnya terdapat hati. Hati tersebut dapat memancarkan cahaya. Adapun cahaya yang ada dalam hati mukmin ibarat ilmu dan hakikat pengetahuan tertinggi (al-ulum wa al-Ma'arif) dan dapat pula dimaknai cahaya yang dimaksud adalah Agama Islam. Thaifur merujuk pendapat Ibnu 'Abbas yang menyatakan: "li din al-islam huwa nur al-Bashirah". Singkatnya, pemaknaan kata "Nur" dalam ayat ini menurut Thaifur dapat digolongkan menjadi dua, yakni ma'nawi dan hissi. Secara ma'nawi adalah cahaya yang menyinari sesuatu dan makna hissi yaitu cahaya yang terdapat dalam hati seorang mukmin. ${ }^{42}$ Dalam konsep tasawuf segala sesuatu yang terjadi dapat dipahami melalui dimensi ma'nawi dan hissi. Ma'nawi yakni suatu perkara yang dapat dirasakan oleh panca indera. Sementara hissi yang berarti segala perkara rahasia Allah yang tidak dapat dirasakan kecuali dengan ilmu dan zauq. ${ }^{43}$

42 Abu Muhammad Thaifur Ali Wafa, Firdaus al-Naim Bi Tudih Ma'na Ayat Alquran alKarim, Jilid IV, h. 283

43 Lihat Ibnu 'Ajibah, Mi'raj al-Tashawwuf ila Haqa'iq al-Tasawwuf, (al-Magribi: al-Dar al- 
Dengan demikian, dari penafsiran Thaifur di atas memberikan gambaran bahwa kecenderungan penafsirannya terkesan menyerupai pandangan para sufi dalam memahami makna batin ayat Alquran. Namun bukan berarti semua ayat-ayat dipahami dengan pendekatan batin secara penuh.

\section{Kesimpulan}

Dari uraian terhadap Tafsir Firdaus al-Nai'm yang disusun oleh Thaifur Ali Wara di atas dapat ditarik kesimpulan sebagai berikut :

Pertama, Kitab Tafsir Firdaus al-Naim yang ditulis oleh Thaifur dibangun dalam metode yang valid dan tetap mengikuti tradisi metodologi tafsir ulama-ulama pendahulunya. Dalam penyajian penafsirannya, Thaifur cenderung terkesan mengutip dari pendapat ahli tafsir lainnya. Oleh karena itu, orisinalitas pemikiran mufasir yang tertuang dalam tafsir ini tidak terlalu dominan. Akan tetapi hal itu tidak mengurangi kapasitas seorang Thaifur sebagai mufasir. Berbagai karya yang ditulisnya membuktikan sosoknya layak disebut sebagai ulama yang produktif. Setidaknya, dengan kehadiran Tafsir Firdaus al-Nai'm ini menambah perbendaharaan literatur tafsir di Indonesia.

Kedua, dalam menafsirkan ayat-ayat Alquran tafsir ini menggunakan pendekatan yang mengombinasikan tafsir bi al-ma'tsur dan bi al-ra'yi. Dalam menguraikan makna Alquran, tafsir ini menggunakan analisis ijmali yang disajikan dengan penjelasan singkat.

\section{DAFTAR PUSTAKA}

al-Qattan, Manna, Mabahits fi ulum Alquran, Terj. Aunur Rafiq ElMazni, Jakarta: Pustaka al-Kautsar, 2006 al-Shabuni, Ali Shafwa al-Tafasir, Beriut: Darul al-Fikr, 1987 Ibnu 'Ajibah, Miraj al-Tashawwuf ila Haqa'iq al-Tasawwuf, al-Magribi: al-Dar al-Baidha', ttt. 
Anwar, Rosihan, Ilmu Tafsir, Bandung: Pustaka Setia, 2000

Setia, 2000

Baidan, Nashruddin, Wawasan Baru ilmu Tafsir, Pustaka Pelajar: Yogyakarta, 2005

Pustaka Pelajar, 2002

Bruinessen, Martin Van Kitab Kuning, Pesantren dan Tarekat: Tradisi Islam di Indonesia, Bandng: Mizan, 1995

Gusmian, Islah, Khazanah Tafsir Indonesia: dari Hermeneutika hingga Ideologi, Yogyakarta: Lkis, 2013

----------, Bahasa dan Aksara dalam Penulisan Tafsir Alquran di Indonesia Era Abad 20 M, Jurnal Mutawatir, No. 2 Vol. 2 JuliDesember 2015.

Jamil, M. Pergeseran Epistemologi Dalam Tradisi Penafsiran Alquran, Jurnal Ilmiah Abdi Ilmu Vol. 4 No. 1 Juni 2011

Lewishon dkk, Leonard, Warisan Sufi: Sufisme Persia Klasik hingga Rumi (7001300-), Terj. Gafna Raizha Wahyudi, Yogyakarta:Pustaka Sufi, 2002

Mustaqim, Abdul, Epistemologi Tafsir Kontemporer, Yogyakarta : LKiS, 2010

Rusli, Ris'an Tasawuf dan Tarekat : Studi Pemikiran dan Pengalaman Sufi, (Jakarta: RajaGrafindo, 2013.

Rohmana, Jajang A. , Kajian Alquran di Tatar Sunda: Sebuah Penelusuran Awal, Suhuf, Vol. 6, No. 1

Salahuddin, Tafsir Ayat Cahaya Dalam Misykat Al-Anwar dan Orientas Pendidkan Potensi Diri, Jurnal Lentera Pendidikan, Vol. 12, No. 1 Juni 2009

Sands, Kristin Zahra, Sufi Commentaries on The Quran in Classical Islam, London \& New York, 2006. 
Shihab, Qurasih dkk, Sejarah dan Ulum Alquran, Jakarta: Pustaka Firdaus, 2008

,Membumikan Alquran:Fungsi dan Peran Wahyu dalam Kehidupan Masyarakat, Bandung: Pustaka Mizan, 2009

Wafa, Thaifur Ali, Firdaus al-Naim bi Tudih Ma'na Ayat Alquran alKarim, ttt. 